\title{
URINARY EXCRETION AND SERUM CONCENTRATION OF INORGANIC PHOSPHATE IN MAN ${ }^{1,2}$
}

\author{
BY ROBERT W. OLLAYOS AND ALEXANDER W. WINKLER
}

\author{
(From the Department of Internal Medicine, Yale University School of Medicine, and the \\ Medical Service of the New Haven Hospital, New Haven)
}

(Received for publication August 19, 1942)

The relationship in man between the concentration of inorganic phosphate ${ }^{3}$ in serum and its rate of excretion in urine forms the subject of this paper. A particular attempt has been made to distinguish between those variations in the excretion rate which passively reflect changes in serum $\mathrm{P}$ concentration and those which are due to other causes. Two general types of experiments have been employed. In the first type, no $P$, other than that in the usual diet, was supplied. The concentration of $\mathrm{P}$ in serum and its rate of excretion in the urine were compared under a variety of circumstances. Normal diurnal variations, the effects of the ingestion of food and water, sleep, activity, and the injection of insulin, were all considered. In the second group of experiments, the relationship between renal excretion of $P$ and the concentration of $P$ in serum was studied after the latter had been artificially raised by the intravenous infusion of phosphate. Such observations in man have apparently never before been described, except for one observation by Schultz (1), at moderate elevations of the serum $P$.

\section{MATERIAL AND METHODS}

The experimental subjects included normal individuals and patients with diabetes mellitus. Urine specimens were collected in successive intervals by voluntary voiding, every effort being made to make the collections as complete as possible. Blood specimens under oil were obtained from time to time, allowed to clot, and the serum promptly withdrawn. Inorganic phosphate was determined by the macro method of Fiske and Subbarow (2). Ultrafiltrates of serum were obtained by the

1 From a thesis submitted by Robert W. Ollayos to the Yale University School of Medicine in partial fulfillment of the requirements for the degree of Doctor of Medicine, 1941.

2 Aided by grants from the Ella Sachs Plotz Fund and from the Fluid Research Fund, Yale University School of Medicine.

s Hereafter the symbol "P" will represent "inorganic phosphate." method of Lavietes (3). Diurnal variations of renal excretion were studied in a healthy, young, adult, medical student ( $R$. O.). In most of the experiments, collections were begun about seven in the morning and continued at approximately hourly intervals throughout the day and evening. Blood samples were obtained five or six times during the experiment. The intervals between were somewhat irregular, since some attempt was made to obtain samples in as close a relation as possible to changes in the rate of urinary excretion of $P$. The subject fasted from the preceding evening until the end of the observation period. Water was given at the rate of $200 \mathrm{cc}$. per hour during the day of the experiment. The subject remained ambulatory during the period of observation, reading, writing, or doing simple laboratory tasks; no strenuous exertion or exercises were performed. On some days, the customary hours of waking and sleeping were reversed. The subject breakfasted about seven a.m., then fasted for the next twenty-four hours. Collections of urine were started at seven p.m. of the same day and continued throughout the night. The subject slept in the afternoon, and stayed awake all night while urine and blood samples were being collected.

Serum $\mathbf{P}$ and renal excretion rate of $\mathbf{P}$ were studied in three hospitalized, diabetic patients under insulin therapy. The dietary and therapeutic schedules were not disturbed. Serum $P$ and urinary excretion rate of $P$ were followed in relation to meals and to insulin therapy during the morning and early afternoon, in very much the same way that they were studied in the normal subject.

Four subjects, three normal and one with mild essential hypertension, received infusions of $500 \mathrm{cc}$. of isotonic neutral sodium phosphate solution. The phosphate solution was made up by dissolving 12.33 grams of $\mathrm{Na}_{2} \mathrm{HPO}_{4}$ $\times 12 \mathrm{H}_{2} \mathrm{O}$ and 1.12 grams of $\mathrm{NaH}_{2} \mathrm{PO}_{4} \times \mathrm{H}_{2} \mathrm{O}$ in approximately $500 \mathrm{cc}$. of freshly distilled water. The solution was sterilized by boiling, and brought to exactly $\mathbf{5 0 0}$ cc. volume, by the addition of sterile distilled water, just before giving. A sample was always tested with a phenol red indicator to be certain that its $\mathrm{pH}$ was not above 7.3. The infusion was given over a period of 30 to 40 minutes. None of the patients had subjective symptoms of discomfort or objective evidences of reaction during or after the infusion. Numbness, tingling, and tetany were entirely absent. Following the infusion, blood and urine samples were obtained at intervals of forty-five to ninety minutes, the exact intervals being indicated in Table I. The experiments continued for six to eleven hours after the infusion; the subjects received water at 
TABLE I

Intravenous infusion of neutral isotonic sodium phosphate solution

\begin{tabular}{|c|c|c|c|c|c|c|c|c|c|}
\hline \multirow{2}{*}{$\begin{array}{l}\text { Experiment } \\
\text { number } \\
\text { Body weight }\end{array}$} & \multirow{2}{*}{ Period } & \multirow{2}{*}{ Duration } & \multirow{2}{*}{ Urine flow } & \multicolumn{2}{|c|}{$\begin{array}{l}\text { Concentration of } \\
\text { inorganic phosphate }\end{array}$} & \multirow{2}{*}{$\begin{array}{c}\text { Clearance of } \\
\text { inorganic } \\
\text { phosphate }\end{array}$} & \multicolumn{2}{|c|}{$\begin{array}{l}\text { Distribution of inorganic } \\
\text { phosphate }\end{array}$} & \multirow{2}{*}{ Remainder } \\
\hline & & & & Urine & Serumt & & $\begin{array}{l}\text { Recovered } \\
\text { from urine }\end{array}$ & $\begin{array}{l}\text { Present in } \\
\text { extracellular } \\
\text { fluid }\end{array}$ & \\
\hline $\begin{array}{l}\text { kgm. } \\
77.8\end{array}$ & $\begin{array}{c}1 \\
2 \\
3 \\
4 \\
5^{*} \\
6 \\
7 \\
8 \\
9 \\
10 \\
11\end{array}$ & $\begin{array}{c}\text { minutes } \\
35 \\
65 \\
58 \\
157 \\
52 \\
53 \\
40 \\
45 \\
60 \\
60 \\
60\end{array}$ & $\begin{array}{c}\text { cc. per minute } \\
6.23 \\
2.20 \\
2.19 \\
0.82 \\
3.04 \\
2.49 \\
1.80 \\
1.16 \\
1.09 \\
1.01 \\
0.68\end{array}$ & $\begin{array}{l}m g m \\
3 \\
12 \\
36 \\
55 \\
314 \\
395 \\
457 \\
464 \\
345 \\
263 \\
301\end{array}$ & $\begin{array}{r}100 c c . \\
3.99 \\
3.48 \\
17.35 \\
10.80 \\
7.59 \\
6.00\end{array}$ & $\begin{array}{c}\text { cc. per minute } \\
5 \\
7 \\
21 \\
13 \\
73 \\
84 \\
63 \\
53 \\
43\end{array}$ & $\begin{array}{l}32 \\
50 \\
56 \\
\\
64\end{array}$ & $\begin{array}{l}48 \\
27 \\
20\end{array}$ & $\begin{array}{l}20 \\
23 \\
24\end{array}$ \\
\hline 2. 77.6 & $\begin{array}{r}1 \\
2 \\
3 \\
4 \\
5^{*} \\
6 \\
7 \\
8 \\
9 \\
10\end{array}$ & $\begin{array}{r}60 \\
120 \\
60 \\
120 \\
28 \\
32 \\
45 \\
40 \\
50 \\
195\end{array}$ & $\begin{array}{l}0.73 \\
0.79 \\
1.80 \\
0.37 \\
4.64 \\
3.72 \\
3.96 \\
2.92 \\
1.88 \\
0.81\end{array}$ & $\begin{array}{r}44 \\
44 \\
61 \\
12 \\
198 \\
303 \\
216 \\
167 \\
232 \\
259\end{array}$ & $\begin{array}{r}2.52 \\
\\
3.15 \\
18.91 \\
12.51 \\
8.78 \\
7.08\end{array}$ & $\begin{array}{l}13 \\
13 \\
38 \\
14 \\
\\
72 \\
70 \\
51 \\
55\end{array}$ & $\begin{array}{l}20 \\
\\
37 \\
44 \\
55\end{array}$ & $\begin{array}{l}61 \\
37 \\
26\end{array}$ & $\begin{array}{l}19 \\
26 \\
30\end{array}$ \\
\hline 3. 86.4 & $\begin{array}{l}1 \\
2 \\
3 \\
4 \\
5^{*} \\
6 \\
7 \\
8 \\
9\end{array}$ & $\begin{array}{r}60 \\
35 \\
90 \\
43 \\
57 \\
42 \\
90 \\
68 \\
120\end{array}$ & $\begin{array}{l}0.61 \\
0.56 \\
0.35 \\
1.72 \\
8.98 \\
9.76 \\
3.31 \\
1.19 \\
0.82\end{array}$ & $\begin{array}{r}65 \\
52 \\
54 \\
38 \\
133 \\
118 \\
161 \\
276 \\
275\end{array}$ & $\begin{array}{r}2.69 \\
\\
3.33 \\
13.43 \\
7.35 \\
5.46\end{array}$ & $\begin{array}{r}15 \\
11 \\
6 \\
22 \\
\\
105 \\
73 \\
63\end{array}$ & $\begin{array}{l}37 \\
52 \\
68\end{array}$ & $\begin{array}{l}29 \\
15\end{array}$ & $\begin{array}{l}34 \\
33\end{array}$ \\
\hline 4. 56.3 & $\begin{array}{c}1 \\
2^{*} \\
3 \\
4 \\
5 \\
6 \\
7 \\
8 \\
9 \\
10 \\
11 \\
12 \\
13\end{array}$ & $\begin{array}{r}65 \\
69 \\
43 \\
37 \\
45 \\
45 \\
75 \\
45 \\
75 \\
65 \\
55 \\
60 \\
120\end{array}$ & $\begin{array}{l}2.38 \\
4.97 \\
2.60 \\
2.54 \\
2.82 \\
2.60 \\
2.68 \\
8.00 \\
3.80 \\
7.15 \\
0.80 \\
0.92 \\
2.75\end{array}$ & $\begin{array}{r}12 \\
167 \\
406 \\
251 \\
189 \\
79 \\
45 \\
30 \\
39 \\
16 \\
128 \\
120 \\
40\end{array}$ & $\begin{array}{r}3.19 \\
20.07 \\
9.60 \\
7.08 \\
\\
4.98 \\
4.54 \\
3.71\end{array}$ & $\begin{array}{r}9 \\
79 \\
55 \\
58 \\
28 \\
19 \\
42 \\
30 \\
27 \\
26 \\
29\end{array}$ & $\begin{array}{l}40 \\
47 \\
\\
54 \\
56 \\
59 \\
\\
62\end{array}$ & $\begin{array}{l}30 \\
18 \\
\\
8 \\
6 \\
2\end{array}$ & $\begin{array}{l}30 \\
35 \\
\\
38 \\
38 \\
39\end{array}$ \\
\hline
\end{tabular}

* Injection given during this period.

† Sample at end of period.

the rate of $200 \mathrm{cc}$. per hour, but no food. Clearances of $P$ were calculated by a method previously described (4).

\section{RESULTS}

\section{(A) Excretion in the normal fasting subject}

In Figure 1A are presented the diurnal variations of $\mathrm{P}$ excretion, and of serum $\mathrm{P}$, in the normal fasting subject, on a single typical day. The excretory rate first fell off sharply during the second hour after arising, then gradually increased during the late morning hours, reaching a maximum in the early afternoon. In experiments in which the customary rhythmn of sleeping and waking was reversed (Figure 1B), the excretory rate fell off sharply in the second hour after the subject had arisen, just as it did in the early morning hours of the control experiments. However, instead of increasing again after 2 or 


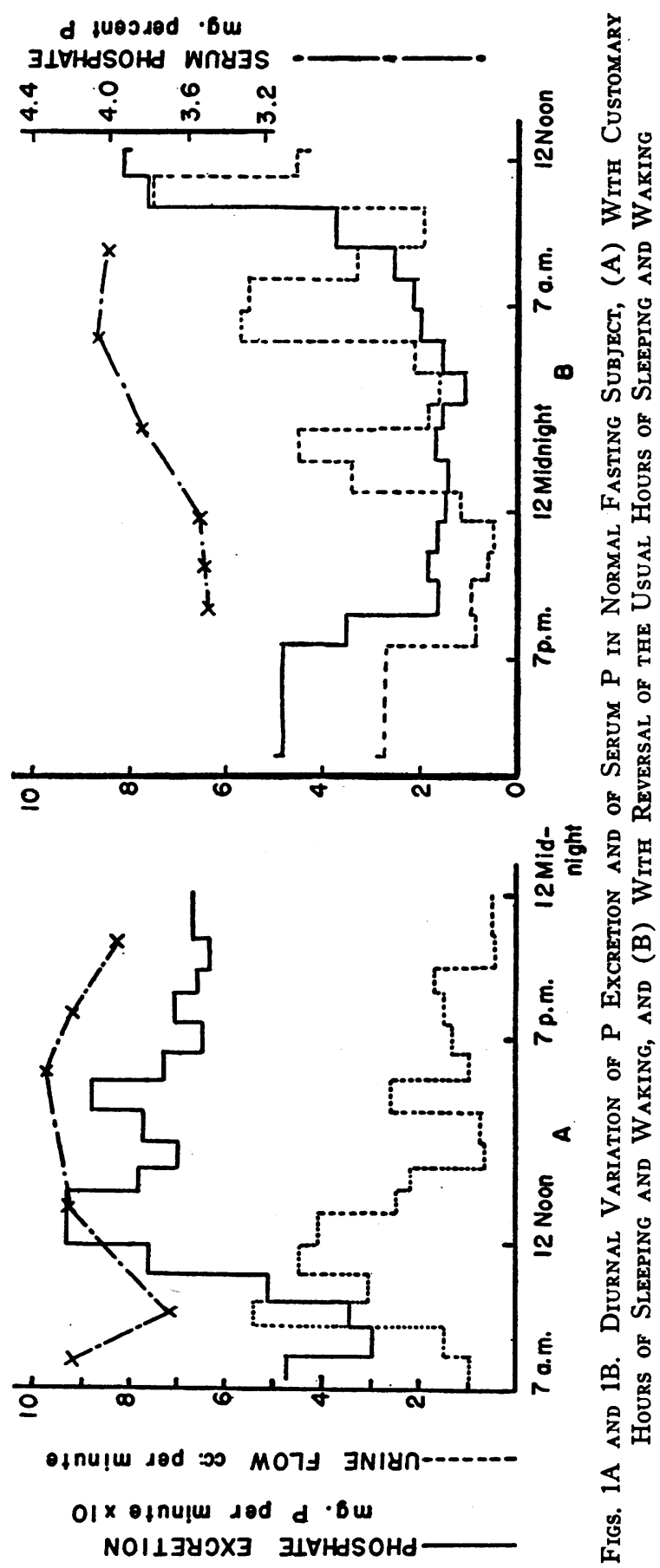

3 hours, the rate of excretion persisted at a low level for another three to nine hours. The transitory increase in the excretory rate of $\mathrm{P}$ at about 2 a.m. did not always appear. After falling off for a time, the rate of excretion once again increased markedly during the morning hours after a sleepless night. The characteristic curve of $P$ excretion in this group of observations (Figure 1B), therefore, differs in form from that of the same subject with a normal cycle of sleeping and waking (Figure 1A).

No regular pattern of variation in the serum $P$, corresponding to variations of $P$ excretion in the urine, can be seen in any of these experiments with the normal diurnal variations of $P$ excretion. In four of the six experiments, the serum $P$ concentration decreased between the first and third hour after rising. In one control observation, there was a sharp, unexplained rise in the serum $P$ to $5.7 \mathrm{mgm}$. per cent during the early evening, unassociated with any increase in the renal excretion of $\mathrm{P}$.

\section{(B) Effects of food and insulin}

In Figure 2A, the effects of a high carbohydrate breakfast in a normal subject are shown. No other food was taken during the period of observation. The fall in excretion rate seen in a fasting subject during the second hour after arising is replaced by a moderate rise in excretion rate of $\mathrm{P}$ immediately after breakfast. Similar results were obtained in two other subjects. The rate soon falls off again, and the remainder of the daily cycle is indistinguishable from that of the completely fasting subject.

In the three diabetic subjects receiving insulin, there was, on the other hand, an initial decrease both in the serum $P$ and in the urinary excretion rate of $P$ following breakfast and insulin (Figure 2B). No good quantitative relationship and no exact synchrony could, however, be established between serum $P$ and urinary excretion rate of P. Thus, in the experiment of Figure 2B, serum $P$ concentration was still decreasing at the same time that the renal excretion rate was beginning to return to its initial value. In another experiment, there was an almost complete absence of $P$ from the urine, while the concentration of $P$ in serum was $3.1 \mathrm{mgm}$. per cent, a concentration 

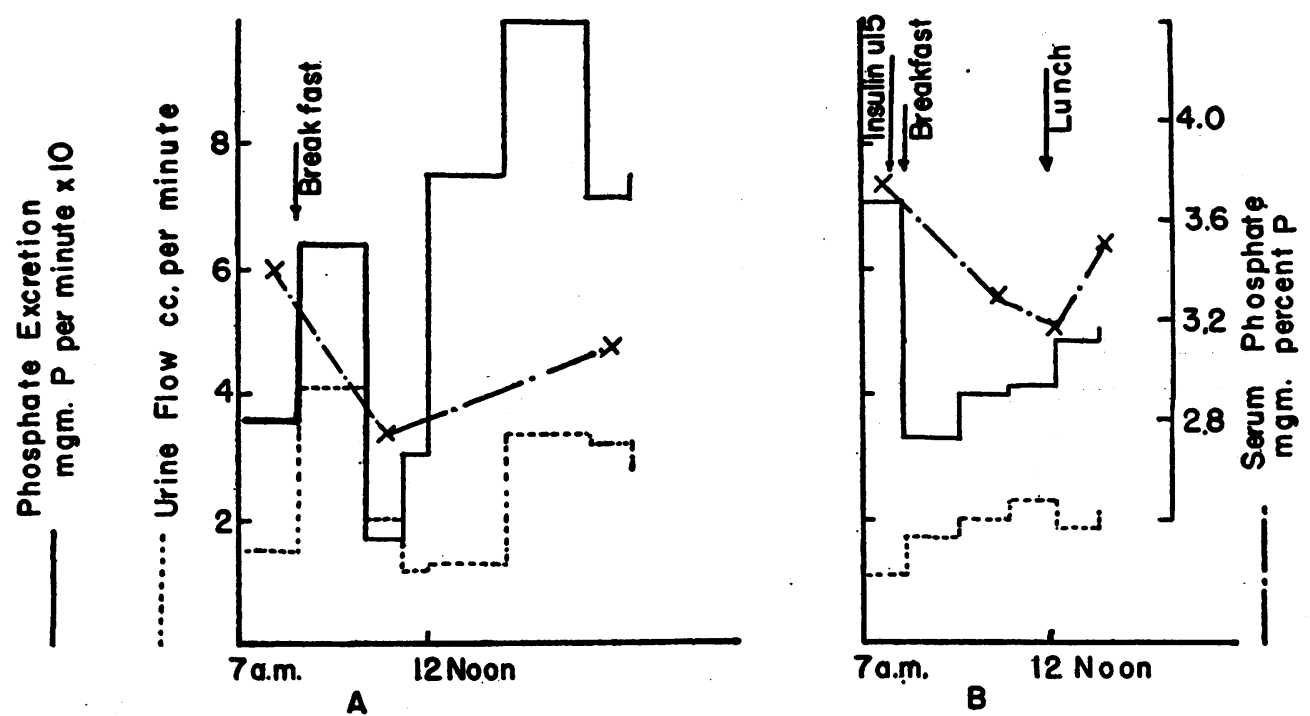

Figs. 2A and 2B. Excretion of P (A) In a Normal Subject Following Breakfast, and (B) In a Diabetic Subject Following Insulin and Breakfast

commonly associated with much higher rates of excretion of $\mathrm{P}$ in the urine.

\section{(C) Statistical relationships of urinary excretion of $P$ to serum $P$ concentration and to rate of urine flow}

In Figure 3, the urinary excretion rate of $P$, in all experiments in which no $P$ was injected, is plotted against corresponding serum concentration. The latter values were obtained by interpolation. There is almost no statistical correlation between the two variables.
In the individual observations of diurnal variations of $\mathrm{P}$ excretion, there was no discernable relationship between the excretion rate of $P$ and the rate of urine flow (Figures 1 and 2). This conclusion is confirmed by the evident lack of correlation between these two variables in Figure 4, in which they are plotted directly against one another.

\section{(D) Effects of infusion of sodium phosphate solution}

The results of four experiments in which neutral isotonic sodium phosphate solution was in-

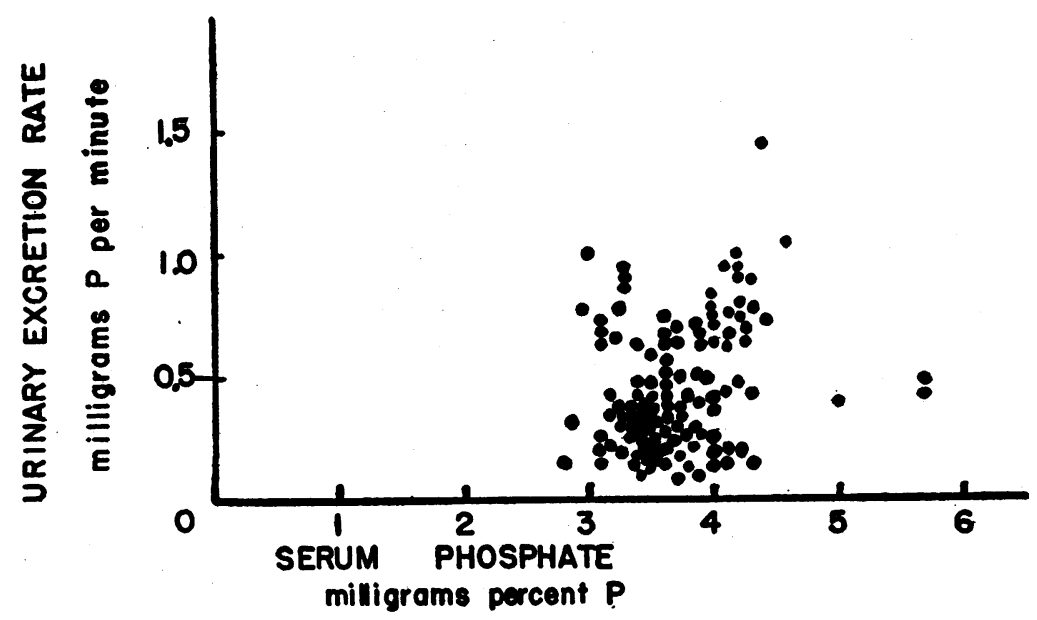

Fig. 3. Relationship Between Serum $P$ and Urinary Excretion Rate of P in All Experiments in Which No P Was Injected 


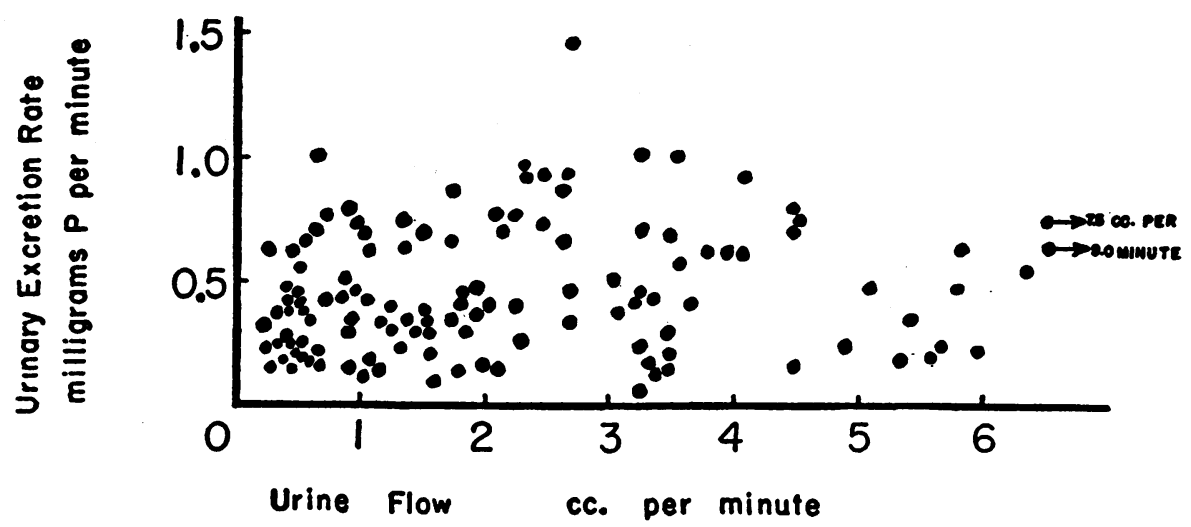

Fig. 4. Relationship Between Urine Flow and Urinary Excretion Rate of. P in All Experiments in Which No P Was Injected

jected intravenously are given in Table I. Enough phosphate was given to increase the serum $\mathrm{P}$ fiveor six-fold. The rate of urinary excretion of $P$ was likewise enormously increased, to a greater degree indeed than was the serum concentration. As a result, the clearance of $\mathrm{P}$ is several times as great at artificially elevated concentration of serum $\mathrm{P}$ than at normal concentrations. As con- centration declined, the clearance of $\mathrm{P}$ also decreased. The exact functional relationship between urine excretion rate and the corresponding mean serum concentration of $\mathrm{P}$ is shown in Figure 5. The lines are nearly straight, and tend to intersect the abscissa at or slightly above the region of normal serum concentration. This close interdependence of the two variables contrasts

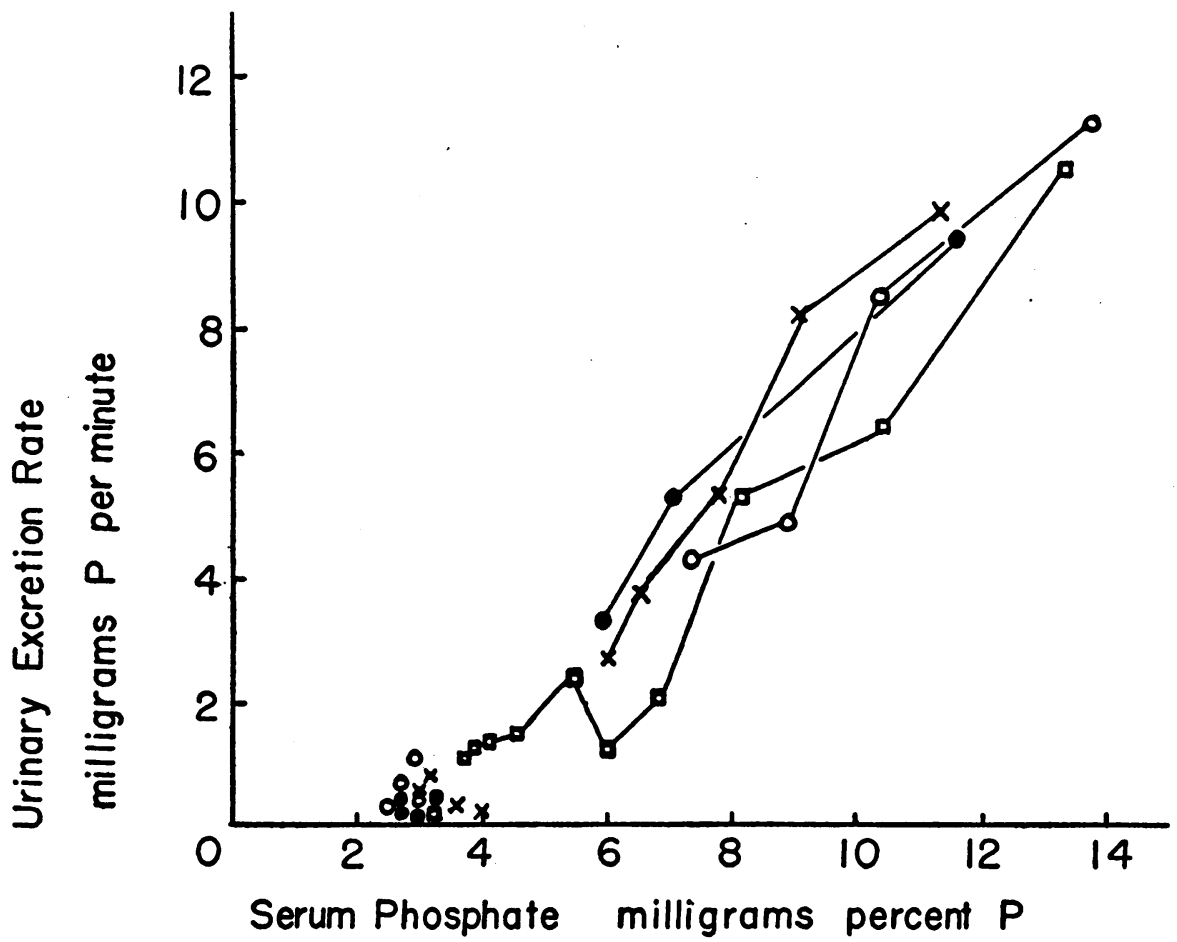

Fig. 5. Relationship Betwwen Serum P and Urinary Excretion Rate of $P$ in Four Experiments in Which Isotonic Neutral Sodium Phosphate Solution Was INJECTED INTRAVENOUSLY 
sharply with the lack of correlation between the two when no $P$ is injected (Figure 3).

Some estimate of the distribution of injected $P$ between cellular and extracellular fluid of the body has been made in the last three columns of Table I. It has been assumed that the extracellular fluid of the body constitutes 25 per cent of the body weight, and that the concentration of $P$ in the extracellular fluid is identical with that in an ultrafiltrate of serum. Ultrafiltrates of serum were made in one experiment (number 4 of Table I), and the concentrations of $P$ in the ultrafiltrates did not differ by more than 5 per cent from the concentrations in the corresponding whole sera. It was therefore assumed in the other experiments that concentration of $\mathrm{P}$ in serum could be used as an approximation of its concentration in ultrafiltrate. The percentage of the injected $P$ present at any time in the extracellular fluid is therefore:

$\frac{\text { Body weight (kgm.) }}{4}$

$X$ Increase in serum $\mathrm{P} \times 10 \times \frac{100}{2985}$,

where the increase in serum $\mathrm{P}$ is expressed in mgm. per cent, and 2985 represents the number of $\mathrm{mgm}$. of $\mathrm{P}$ injected in each experiment. Urinary recovery has been estimated by subtracting an assumed average endogenous $P$ excretion rate of $0.5 \mathrm{mgm}$. per minute from the total urinary excretion of $P$. The difference between the total amount of $P$ injected, on the one hand, and the sum of the $\mathrm{P}$ recovered from the urine and that still present in the extracellular fluid, on the other, must represent $P$ which has entered cells or has been excreted into the gut. Between 20 and 34 per cent of the injected $P$ was regularly present in this "remainder" within the first hour after injection. From that time on, the amount increased very slightly or not at all during the next few hours, while, at the same time, the extracellular fluid was losing its $P$ to the urine. As a result, only 60 to 70 per cent of the injected $P$ was recovered during the course of our experiments, even though in one instance (number 4 of Table I), the serum $\mathrm{P}$ had returned to normal.

\section{DISCUSSION}

Under normal circumstances, the concentration of $P$ in serum evidently does not determine com- pletely the rate of urinary excretion of $\mathrm{P}$, since the latter may vary quite independently of the serum $P$ (Figure 3 ). The fact that no constant parallel change in the concentration of $P$ in serum accompanies the wide variation of urinary $\mathrm{P}$ during the normal diurnal cycle proves that the rate of urinary excretion is much affected by factors other than serum $P$ concentration (Figures $1 \mathrm{~A}$ and $1 B$ ). On the other hand, we know that, after injection of $\mathrm{P}$, changes in concentration of $\mathrm{P}$ in serum are reflected in changes in the rate of urinary excretion of $\mathrm{P}$ (Figure 5). It is also quite possible that the same thing is true under more normal circumstances, except that the changes in the serum $\mathrm{P}$ are usually masked by quantitatively more important changes, due to other causes. For instance, insulin and carbohydrate administration cause a reduction in the serum $P$, due mainly to a passage of $P$ out of the extracellular fluid into the cells (Figure 2B); this reduction is regularly paralleled by a reduction in the rate of urinary excretion of $\mathrm{P}$. It seems reasonable to believe that the change in the rate of urinary excretion is simply a reflection of the change in serum concentration. It is possible that, in a somewhat similar way, the marked increase in the rate of excretion of $\mathrm{P}$ following prolonged acidosis, due to excessive carbon dioxide (5), only reflects the rise in concentration of serum $P$. On the other hand, the increased rate of $P$ excretion, which often follows the ingestion of food by normal subjects not receiving insulin (Figure 2A), is apparently unrelated to changes in the serum $P$. The marked increase in the urinary output of $P$ following parathormone, without much change in the concentration of $P$ in serum (6), indicates that this hormone acts directly on the kidney, rather than indirectly through a control of the serum $P$. If $P$ in urine is derived from serum $P$ passing through the glomerular filter, then variations in tubular reabsorption must be quite as important, under normal circumstances, as variations in the concentration of $\mathrm{P}$ in the glomerular filtrate in governing the rate at which $\mathrm{P}$ is finally excreted in the urine.

In marked contrast to the situation at normal concentrations, serum $\mathrm{P}$ concentration seems to be the main correlative of the rate of renal excretion of $P$ whenever serum concentration is increased well above normal (Table I and Figure 
5). The findings in man in this respect are quite similar to those in the dog ( 8 to 11 ) and in the rabbit (7). In view of the different relationship between serum $P$ and renal excretion rate, at normal and at artificially elevated serum $P$ concentrations, the transition from elevated to normal levels of serum $\mathrm{P}$ are of especial interest. Experiment 4 of Table $I$ is relevant. At a serum $P$ level between 5 and $6 \mathrm{mgm}$. per cent, the previously rapid decline in the serum $P$ suddenly slackened. At the same time, the urinary excretion rate became markedly irregular and lost its previous linear mathematical relationship to serum $P$. This single observation suggests that the shift from a type of excretion closely dependent upon serum concentration to one relatively independent of it may occur fairly rapidly and completely at a critical level of the serum $P$. In this case, the critical level was a little greater than $5 \mathrm{mgm}$. per cent. The solitary observation of Schultz (1) indicates a similar fairly abrupt change in the rate of decline of the serum $P$ at $6 \mathrm{mgm}$. per cent. Urinary excretion was not, however, as clearly dissociated from serum $\mathrm{P}$ concentration below this level as in our experiment.

The kidney is evidently the chief channel through which large sudden additions to the $\mathrm{P}$ of the body are removed, since about two-thirds of the injected $\mathrm{P}$ was recovered from the urine, even before the serum $P$ and the renal excretion rate had returned completely to normal. In addition to the amounts present in the extracellular fluid, there is still a considerable fraction of the injected $\mathrm{P}$ which has been segregated elsewhere in the body. The partition between cells (or bone) and the bowel of this segregated balance is not known. As has been pointed out, the segregation takes place almost entirely within the first hour after infusion. After this time, the fraction increases slowly or not at all, so that there can be little continued excretion into the bowel and little loss from the cells. If any considerable portion of this fraction is, in fact, excreted into the gut, such excretion must take place initially with great speed, then suddenly almost cease. Studies with radioactive $P$ have suggested that, contrary to older beliefs, the only $\mathrm{P}$ normally excreted into the gut is that which forms a part of the intestinal secretions. Our observations on the distribution of injected $\mathrm{P}$ do not indicate any sustained ability of the gut to adjust its excretion of $\mathrm{P}$ to the presence of acute hyperphosphatemia, and are entirely consistent with a negligible increase in excretion into the gut.

The results of the attempt to alter the diurnal $P$ tide by reversing the hours of sleeping and waking are not easily explained in their entirety. The initial fall in the excretory rate of $P$ upon rising in the early evening, after an afternoon's sleep, is similar to that observed in the midmorning hours following a customary sleep during the previous night. This decrease may be related to the increased muscular tone and muscular activity attendant upon waking life (12). The later, long continued reduction of $\mathrm{P}$ excretion, with a reversal of normal waking and sleeping hours, has no counterpart in the normal diurnal pattern of $\mathrm{P}$ excretion. Had the normal tide been completely reversed, or had the usual excretory pattern persisted, a high rate of excretion of $P$ between midnight and 7 a.m. would be expected. Ingestion of food and recovery from exercise, the commonest means of producing a fall in the renal excretion rate of $P$, were excluded by the conditions of the experiment. Although no adequate explanation is available, it is apparent that diurnal variations in $\mathrm{P}$ excretion are not entirely attributable to the transition from a state of sleep to one of wakefulness.

The changes in serum $P$ concentration and renal excretion rate of $P$ in the diabetic subjects following food and insulin confirm the findings of other workers (13 to 16). The increased renal excretion of $\mathrm{P}$ in certain normal subjects following the ingestion of food appears to support the contention that a decrease in the excretion of $\mathrm{P}$ does not invariably follow the administration of carbohydrate (17 to 22 ). The value of this evidence is, however, lessened by the fact that the meals are not purely carbohydrate in composition, and that therefore an unknown amount of fat was ingested along with the carbohydrate.

\section{CONCLUSIONS}

(1) The rate of urinary excretion of $P$ in man under normal circumstances does not depend primarily on the concentration of $\mathrm{P}$ in the serum, although it may be influenced by changes in the latter.

(2) Following the intravenous injection of 
large amounts of neutral isotonic sodium phosphate solution in normal man, the rate of urinary excretion of $P$ is mainly determined by the concentration of $P$ in serum.

(3) Injected $P$ is distributed through a greater volume than that of the extracellular fluid.

\section{REFERENCES}

1. Schultz, I., Phosphorus in the blood and urine: a study of the excretion and retention of phosphorus in a normal subject and in patients with renal disease. Ann. Int. Med., 1930, 3, 667.

2. Fiske, C. H., and Subbarow, Y., The colorimetric determination of phosphorus. J. Biol. Chem., 1925, 66, 375 .

3. Lavietes, P. H., Anaerobic ultrafiltration. J. Biol. Chem., 1937, 120, 267.

4. Winkler, A. W., and Parra, J., The measurement of glomerular filtration. Creatinine, sucrose and urea clearances in subjects without renal disease. J. Clin. Invest., 1937, 16, 859.

5. Haldane, J. B. S., Wigglesworth, V. B., and Woodrow, C. E., Effect of reaction changes on human inorganic metabolism. Proc. Roy. Soc., Lond., 1924, 96, Series B, 1.

6. Goadby, H. K., and Stacey, R. S., On the action of parathormone. Biochem. J., 1934, 28, 2092.

7. Addis, T., Meyers, B. A., and Bayer, L., Regulation of renal activity. XI. Rate of phosphate excretion by the kidney. The effect of variation in the concentration of phosphate in the plasma on the rate of phosphate excretion. Am. J. Physiol., 1925, 72, 125.

8. Adolph, E. F., The chemical sensitiveness of the kidneys. Am. J. Physiol., 1925, 74, 93.

9. Fay, M., Behrmann, V. G., and Buck, D. M., The parathyroids and the clearance of inorganic phosphate. Am. J. Physiol., 1942, 136, 716.

10. Pitts, R., Excretion of urine in the dog. VII. Inorganic phosphate in relation to plasma phosphate level. Am. J. Physiol., 1933, 106, 1.
11. Smith, P. K., Ollayos, R. W., and Winkler, A. W., Tubular reabsorption of phosphate in the dog. $\mathrm{J}$. Clin. Invest., 1943, 22,

12. Kleitman, N., Studies of the physiology of sleep. Effect of muscular activity, rest, and sleep on the urinary excretion of phosphorus. Am. J. Physiol., 1925, 74, 225.

13. Bose, J. P., and De, U. N., Relation of inorganic phosphate to carbohydrate metabolism in normal and diabetic subjects. Indian J. M. Research, 1939, 26, 645.

14. Briggs, A. P., Koechig, I., Doisy, E. A., and Weber, J., Some changes in the composition of blood due to the injection of insulin. J. Biol. Chem., 1924, 58, 721 .

15. Sokhey, S. S., and Allan, F. N., The relation of phosphorus to carbohydrate metabolism. I. The time relations of changes in phosphorus excretion caused by insulin and sugar. Biochem. J., 1924, 18, 1170.

16. Wigglesworth, V. B., Woodrow, C. E., Smith, W., and Winter, L. B., The effect of insulin on the blood phosphate. J. Physiol., 1923, 57, 447.

17. Bachmann, G., Haldi, J., Ensor, C., and Wynn, W., The effects of the ingestion of glucose and of fructose on the rate of excretion of urine and various constituents. Am. J. Physiol., 1938, 124, 77.

18. Blatherwick, N. R., Bell, M., and Hill, E., Some effects of insulin on carbohydrate and phosphorus metabolism of normal individuals. J. Biol. Chem., 1924, 61, 241.

19. Bolliger, A., and Hartman, F. W., Observations on blood phosphates as related to carbohydrate metabolism. J. Biol. Chem., 1925, 64, 91.

20. Harrop, G. A., and Benedict, E. M., Participation of inorganic substances in carbohydrate metabolism. J. Biol. Chem., 1924, 59, 683.

21. McCorvie, J. E., Studies on the morning alkaline tide of urine in normal persons and in patients, with nephritis. J. Clin. Invest., 1925, 2, 35.

22. Reiser, R., Phosphorus changes during the absorption of oil and glucose. J. Biol. Chem., 1940, 135, 303. 